\title{
Preferential use of Siglec-1 or Siglec-10 by type 1 and type 2 PRRSV strains to infect PK15 1 -CD163 and PK15 ${ }^{\text {S10-CD163 }}$ cells
}

\author{
Jiexiong Xie ${ }^{*}$, Isaura Christiaens, Bo Yang, Ivan Trus, Bert Devriendt, Tingting Cui, Ruifang Wei \\ and Hans J. Nauwynck
}

\begin{abstract}
Cellular entry mediators define whether the cell is permissive to PRRSV infection. Porcine sialoadhesin (pSn, Siglec-1) and CD163 are main entry mediators facilitating infection of porcine macrophages by PRRSV. Recently, Siglec-10 was demonstrated to be an alternative receptor for PRRSV. To examine if virulence and pathogenicity of PRRSV strains could be correlated with the use of different Siglecs, a PK15 cell line recombinantly expressing Siglec-1 and CD163

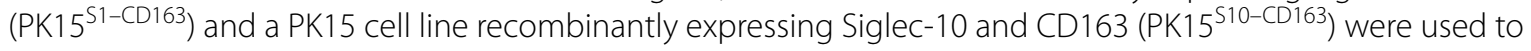
compare the virus replication of 7 genotype 1 subtype 1 strains (G1s1), 2 genotype 1 subtype 3 (G1s3) strains and 5 genotype 2 (G2) strains. Some strains (08VA (G1s1), $13 \mathrm{~V} 117$ (G1s1), 17V035 (G1s1), VR2332 (G2)) were poor virus producers ( $<10^{4} \mathrm{TCID}_{50} / \mathrm{mL}$ ), while other strains (07V063 (G1s1), $13 \mathrm{~V} 091$ (G1s1), Su1-Bel (G1s3), MN-184 (G2), Korea17 (G2) and SDSU-73 (G2)) easily grew up to $\geq 10^{6} \mathrm{TCID}_{50} / \mathrm{mL}$. PK15 $5^{\mathrm{S10}-\mathrm{CD} 163}$ cells exhibited a higher efficiency in virus production per infected cell than the PK15 ${ }^{\mathrm{S1}-\mathrm{CD} 163}$ cells. The G1s1 strains LV and 07V063 infected more cells in the PK15 ${ }^{\mathrm{S1-}}$ CD163, whereas the 94V360 and 08VA strains preferred PK15 $510-\mathrm{CD} 163$. The highly virulent G1s3 strains Lena and Su1-Bel

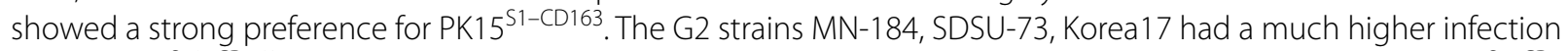
rate in PK15 ${ }^{\text {S10-CD163, while the reference strain VR2332 and the NADC30 strain had a slight preference for PK15 }}{ }^{\text {S1-CD163. }}$ Differences in receptor use may influence the outcome of a PRRSV infection in pigs and explain in part the virulence/ pathogenicity of PRRSV strains.
\end{abstract}

\section{Introduction}

Porcine reproductive and respiratory syndrome virus (PRRSV) is a member of the Arterivirus, genus, family Arteriviridae, order Nidovirales [1] causing respiratory disorders in piglets and reproductive problems in adult animals. PRRSV infections cause major economic losses in the pig industry worldwide [2,3]. In vivo, the virus infects a subpopulation of tissue macrophages, and also subpopulation of monocyte and bone marrow derived dendritic cells [4-9]. In vitro, efficient PRRSV replication is observed in primary porcine alveolar macrophages (PAM), differentiated monocytes [10] and for

\footnotetext{
*Correspondence: jiexiong.xie@ugent.be; hans.nauwynck@ugent.be Department of Virology, Immunology and Parasitology, Faculty of Veterinary Medicine, Ghent University, Salisburylaan 133, 9820 Merelbeke, Belgium
}

certain strains (mainly after adaptation) in African green monkey kidney derived cells, e.g. MARC-145 [11]. Porcine sialoadhesin (pSn, also known as Siglec-1) and porcine CD163 (pCD163) have been reported to be the main entry mediators for PRRSV [12-14]. In the classic PRRSV entry model, the virus binds to and is internalized into the macrophages via $\mathrm{pSn}$ through interacting with the viral GP5/M protein complex. Once inside the cell, pCD163 mediates the viral disassembly and genome release. However, recent studies demonstrated that PRRSV do not only infect sialoadhesin positive, but also sialoadhesin negative cells $[15,16]$. Moreover, Siglec-1 knockout pigs are still susceptible to PRRSV [17]. These results indicated that PRRSV may use alternative entry mediators to infect the host. Indeed, we have recently demonstrated that Siglec-10, a sialic acid binding protein belonging to the same family as Siglec-1, is able to

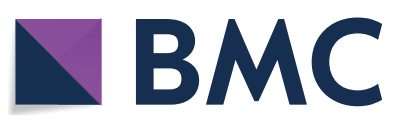

(c) The Author(s) 2018. This article is distributed under the terms of the Creative Commons Attribution 4.0 International License (http://creativecommons.org/licenses/by/4.0/), which permits unrestricted use, distribution, and reproduction in any medium, provided you give appropriate credit to the original author(s) and the source, provide a link to the Creative Commons license, and indicate if changes were made. The Creative Commons Public Domain Dedication waiver (http://creativecommons.org/ publicdomain/zero/1.0/) applies to the data made available in this article, unless otherwise stated. 
facilitate the infection of non-permissive cells by PRRSV [18]. It is very well possible that even more siglecs and/ or siglec-like molecules exist. To analyze the receptor use of different PRRSV strains (7 G1s1, 2 G1s3 and 5 G2), a stably transfected cell line expressing both Siglec-10 and CD163 (PK15 ${ }^{\mathrm{S} 10-\mathrm{CD} 163}$ ) was established and compared with the earlier developed cell line stably expressing both Siglec-1 and CD163 (PK15 ${ }^{\text {S1-CD163 }}$ [10].

\section{Materials and methods}

\section{Cells and viruses}

PK15 cells were cultivated in Dulbecco's Modified Eagle Medium (D-MEM) supplemented with $10 \%$ fetal bovine serum (FBS), $100 \mathrm{U} / \mathrm{mL}$ penicillin, $0.1 \mathrm{mg} / \mathrm{mL}$ streptomycin. MARC-145 cells, PK15 $5^{\mathrm{S} 1-\mathrm{CD} 163}$ and PK15 $15^{\mathrm{S} 10-}$ CD163 cells were cultivated in Modified Eagle Medium (MEM), supplemented with 10\% FBS, $100 \mathrm{U} / \mathrm{mL}$ penicillin, $0.1 \mathrm{mg} / \mathrm{mL}$ streptomycin. The following PRRSV strains were analyzed in our study: LV (prototype G1s1, 13 passages in PAM), 94V360 (G1s1, 3 passages in PAM), 07V063 (G1s1, 3 passages in PAM), 08VA (G1s1, 4 passages in PAM), 13V091 (G1s1, 4 passages in PAM), 13V117 (G1s1, 3 passages in PAM), 17V035 (G1s1, 2 passages in PAM), Lena (G1s3, 4 passages in PAM), Su1-Bel (G1s3, 4 passages in PAM), VR-2332 (G2, 4 passages in MARC-145 and 2 passages in PAM), MN-184 (G2, 3 passages in MARC-145 and 3 passages in PAM), SDSU-73 (G2; 3 passages in MARC-145 and 3 passages in PAM), NADC30 (G2, 3 passages in MARC-145 and 3 passages in PAM) and Korean17 (3 passages in PAM). Information on the origin and virus characteristics are summarized in Table 1.

\section{Transfection and clone selection}

PK15 cells were transfected in the presence of lipofectamine 3000 (Invitrogen) according to the manufacturer's instructions. PK15 cells were first transfected with a plasmid containing the Siglec-10 cDNA and a geneticin resistance gene as described previously [18]. Afterwards, the obtained PK15 ${ }^{\mathrm{S} 10}$ cells were transfected with a plasmid containing the CD163 cDNA and a zeocin resistance gene and single cell cloned. For the selection of PK15 $15^{\mathrm{S} 10-}$ CD163 cells, zeocin $(200 \mu \mathrm{g} / \mathrm{mL}$, Invitrogen $)$ was used. Cells were further sorted and subcloned three times with a FACSAria III (Becton-Dickinson) to obtain stably expressing cell clones (Figure 1).

\section{Fluorescence activated cell sorting (Facs)}

Cells were trypsinized with $0.075 \%$ trypsin (SigmaAldrich) and washed 2 times and harvested with MEM containing $1 \mathrm{mM}$ EDTA and 1\% FBS. The cells were labeled with anti-CD163 monoclonal antibodies (2A10, $\mathrm{IgG}_{1}, \mathrm{AbD}$, serotec) or $\mathrm{mAb}$ against siglec-10 [18]. Isotype-matched monoclonal antibodies (13D12, directed against PRV gD) [19] were used as control. The incubation was performed in the presence of $1 \mathrm{mM}$ EDTA and $1 \%$ FCS for $30 \mathrm{~min}$ on ice. AlexaFluor 647-conjugated polyclonal antibodies against mouse $\operatorname{IgG}_{1}$ (Invitrogen)

Table 1 Information on the virus strains used in the study

\begin{tabular}{|c|c|c|c|c|c|c|c|c|}
\hline Strain & Year of isolation & Origin & $\begin{array}{l}\text { Passages in MARC- } \\
\text { 145/PAM }\end{array}$ & $\begin{array}{l}\text { Virulence } \\
\text { score }\end{array}$ & $\begin{array}{l}\text { Macrophage (mø) } \\
\text { tropism }\end{array}$ & Genotype & Accession number & References \\
\hline LV & 1991 & Netherlands & 13 in PAM & $1+$ & $\mathrm{Sn}^{+} \mathrm{m} \varnothing$ & G1s1 & M96262 & {$[28]$} \\
\hline $94 \vee 360$ & 1994 & Belgium & 3 in PAM & NA & NA & G1s1 & $J F 304781$ & {$[31]$} \\
\hline 07V063 & 2007 & Belgium & 3 in PAM & $3+$ & $\mathrm{Sn}^{+}$and $\mathrm{Sn}^{-} \mathrm{m} \varnothing$ & G1s1 & GU737264 & {$[16]$} \\
\hline 08VA & 2008 & Belgium & 4 in PAM & 0 & $\mathrm{Sn}^{+}$and $\mathrm{Sn}^{-} \mathrm{m} \varnothing$ & G1s1 & GU737266 & {$[16]$} \\
\hline 13V091 & 2013 & Belgium & 4 in PAM & $4+$ & $\mathrm{Sn}^{+}$and $\mathrm{Sn}^{-} \mathrm{m} \varnothing$ & G1s1 & KT159248 & {$[16]$} \\
\hline $13 \vee 117$ & 2013 & Belgium & 3 in PAM & 0 & $\mathrm{Sn}^{+}$and $\mathrm{Sn}^{-} \mathrm{m} \varnothing$ & G1s1 & KT159249 & {$[16]$} \\
\hline 17V035 & 2017 & Belgium & 2 in PAM & 0 & NA & G1s1 & This study & NA \\
\hline Lena & 2007 & Belarus & 4 in PAM & $6+$ & $\mathrm{Sn}^{+}$and $\mathrm{Sn}^{-} \mathrm{m} \varnothing$ & G1s3 & JF802085 & {$[32]$} \\
\hline SU1-Bel & 2010 & Belarus & 4 in PAM & $5+$ & NA & G1s3 & KP889243 & {$[33]$} \\
\hline VR2332 & 1990 & USA & $\begin{array}{l}4 \text { in MARC- } 145 \text { and } 2 \\
\text { in PAM }\end{array}$ & $2+$ & $\mathrm{Sn}^{+}$and $\mathrm{Sn}^{-} \mathrm{m} \varnothing$ & $\mathrm{G} 2$ & U87392 & {$[34]$} \\
\hline SDSU-73 & 1995 & USA & $\begin{array}{l}3 \text { in MARC }-145 \text { and } 3 \\
\text { in PAM }\end{array}$ & $4+$ & NA & $\mathrm{G} 2$ & JN654458 & {$[28]$} \\
\hline MN-184 & 2001 & USA & $\begin{array}{l}3 \text { in MARC }-145 \text { and } 3 \\
\text { in PAM }\end{array}$ & $5+$ & $\mathrm{Sn}^{+}$and $\mathrm{Sn}^{-} \mathrm{m} \varnothing$ & $\mathrm{G} 2$ & EF488739 & {$[28]$} \\
\hline NADC-30 & 2008 & USA & $\begin{array}{l}3 \text { in MARC }-145 \text { and } 3 \\
\text { in PAM }\end{array}$ & $3+$ & NA & G2 & JN654459 & {$[28]$} \\
\hline Korean 17 & 2017 & Korean & 3 in PAM & NA & NA & G2 & This study & NA \\
\hline
\end{tabular}

NA: not available; S1: PK-15 ${ }^{\mathrm{S1-CD} 163} ; \mathrm{S} 10: \mathrm{PK}-15^{\mathrm{S10-CD163}} ; \mathrm{G} 1$ s1: type1 subtype $1 ; \mathrm{G} 1$ s3: type1 subtype 3; G2: type 2 


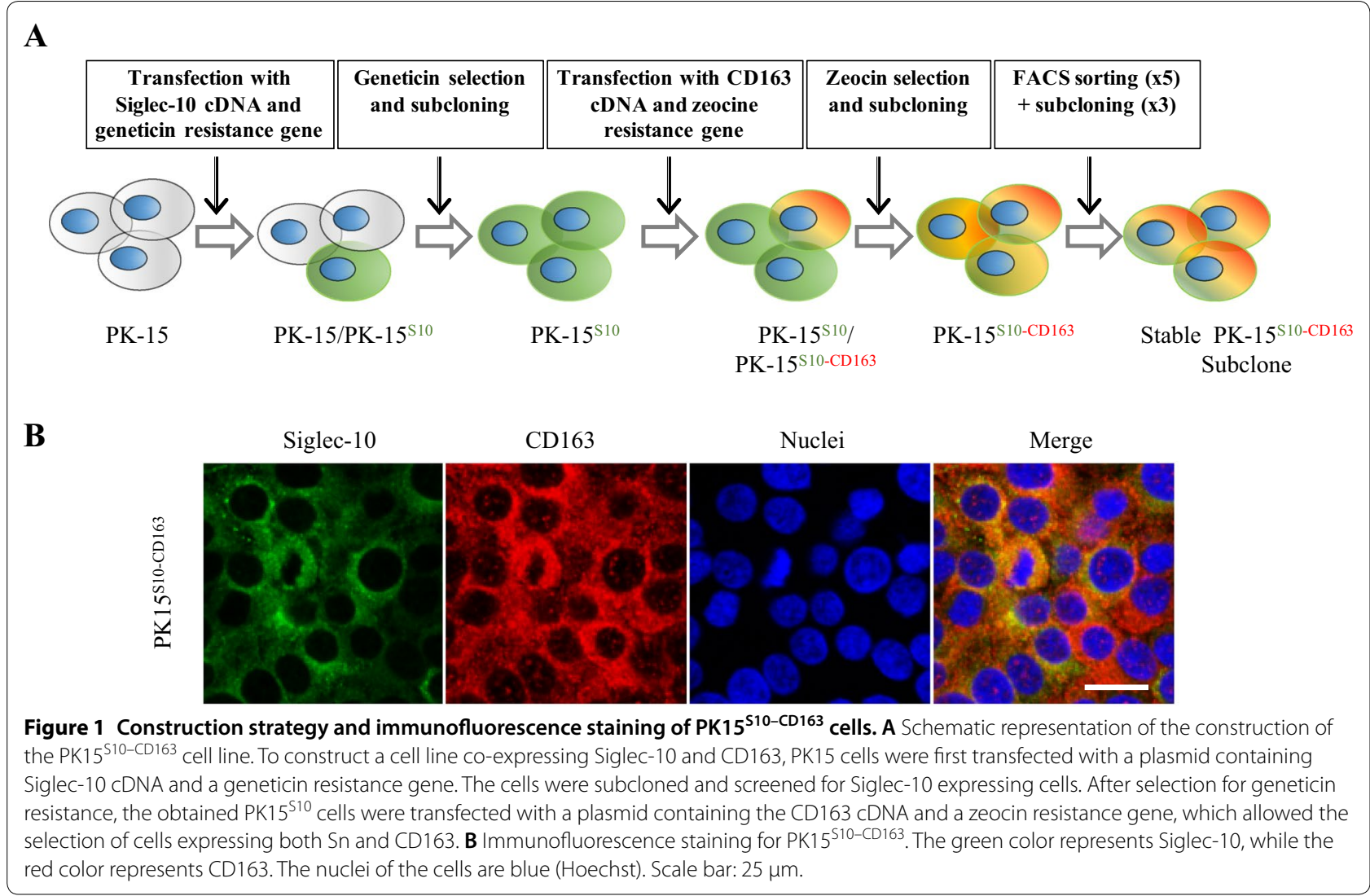

were used as secondary antibodies. Incubation was performed in the presence of $1 \mathrm{mM}$ EDTA and 1\% FCS for $30 \mathrm{~min}$ on ice in the dark. FACS sorting was performed with a FACSAria III. Two million cells were used for each sorting, doublets were excluded with a gating strategy based on forward light scatter and sideward light scatter. Dead cells were excluded with propidium iodide staining. Sorted cells were collected in the RPMI/DMEM (1:1) supplemented with $30 \%$ FCS, $1 \% \mathrm{P} / \mathrm{S}$ and $0.5 \%$ gentamicin and directly used for a subcloning strategy. Subcloning was performed by limiting dilution as described for cloning of hydridomas [20]. The expression of Siglec-10 and CD163 in the subclones was checked by immunofluorescence.

\section{Immunofluorescence staining}

Cells were fixed with methanol for single stainings. Primary monoclonal antibodies were used: mAb $1 \mathrm{G} 10$ against Siglec-10 $\left(\operatorname{IgG}_{1}\right)$ [18]; mAb 41D3 against Siglec-1 [21] or mAb $2 A 10$ against CD163 (IgG 1 , AbD, serotec). $13 \mathrm{D} 12$ was used as isotype control. As a secondary antibody, fluorescein isothiocyanate (FITC)-conjugated polyclonal goat anti-mouse IgG antibodies (Invitrogen) were used. The expression of Siglec-1, Siglec-10 and CD163 was examined with a fluorescence microscope (Leica
Microsystems $\mathrm{GmbH}$, Germany). For double staining of Siglec-10 and CD163, goat polyclonal antibodies against CD163 (R\&D Systems, Minneapolis) and mAb 1 G10 against Siglec-10 were incubated at $37^{\circ} \mathrm{C}$ for $1 \mathrm{~h}$. After three washes with PBS, cells were incubated with rabbit anti-goat AF594 for $1 \mathrm{~h}$ at $37^{\circ} \mathrm{C}$. After blocking with negative goat serum for $30 \mathrm{~min}$ at $37^{\circ} \mathrm{C}$ cells were further incubated with FITC-labelled goat anti-mouse IgG. Cell nuclei were stained with Hoechst 33342.

\section{Flow cytometry}

PK15 ${ }^{\mathrm{S} 10-\mathrm{CD} 163}$, PK15 ${ }^{\mathrm{S} 1-\mathrm{CD} 163}$ and PK-15 cells were trypsinized with $0.075 \%$ trypsin (Sigma-Aldrich). $10^{6}$ cells of each cell line were collected for each experimental condition. Cells were washed two times with PBS. For intracellular staining, cells were fixed with $4 \% \mathrm{PF}$ and permeabilized with $0.1 \%$ triton before incubation with primary antibodies. For surface staining, cells were directly incubated with the primary antibodies against CD163 (mouse IgG ${ }_{1}, 2 \mathrm{~A} 10$ ), Siglec-10 (mouse IgG 1 , 1G10), Sn (mouse IgG 1 , 41D3), PRV gD (isotype matched control $\mathrm{mAb}$ mouse $\left.\mathrm{IgG}_{1}, 13 \mathrm{D} 12\right)$. AF647-conjugated goat antimouse IgG $\mathrm{I}_{1}$ antibodies (Invitrogen) were used as secondary antibodies. The staining procedures were the same as described for Facs above. Flow cytometry was performed 
with Cytoflex (Beckman coulter). 10000 events were recorded and 1000 events were displayed, doublets were excluded with a gating strategy based on forward light scatter and sideward light scatter.

Analysis of PRRSV attachment, internalization, disassembly and infection in PK15 $5^{\mathrm{S1-CD} 163}$ and PK15 $5^{\mathrm{S10-CD163}}$ cells by immunofluorescence

Cells were seeded at $2 \times 10^{5}$ cells $/ \mathrm{mL}(1 \mathrm{~mL} /$ well in 24-well plate) and after 3 days of cultivation, cells were inoculated with PAM grown LV at a multiplicity of infection (MOI) of 1 . After $1 \mathrm{~h}$ of incubation at $4{ }^{\circ} \mathrm{C}$, cells were fixed with methanol in order to assess virus attachment. To quantify the internalized particles, to analyze virus disassembly and virus infection, cells were fixed after 1,5 and $24 \mathrm{~h}$ of incubation at $+37^{\circ} \mathrm{C}$ with ice-cold methanol $\left(-20{ }^{\circ} \mathrm{C}, 10 \mathrm{~min}\right)$. The virus was stained with $\mathrm{mAb} 13 \mathrm{E} 2$, directed against PRRSV nucleocapsid $\left(\operatorname{IgG}_{1}, 1: 50\right)$ and secondary FITC-conjugated polyclonal goat anti-mouse IgG antibodies (Invitrogen, Molecular Probes, Belgium). Virus particles and number of PRRSV infected cells were counted on images acquired with a TCS SPE confocal system (Leica Microsystems GmbH, Germany). Twenty randomly selected fields were taken for calculating the virus particles and percentage of infected cells.

\section{PRRSV infection kinetics in PK15 $5^{\mathrm{S1-CD} 163}$ and PK15 $10-\mathrm{SD} 163$ cells}

PK15 $5^{\mathrm{S} 10-\mathrm{CD} 163}$ and PK15 $5^{\mathrm{S} 1-\mathrm{CD} 163}$ cells were seeded at a concentration of 200000 cells $/ \mathrm{mL}$ in 24 well plates with glass inserts ( $1 \mathrm{~mL} /$ well). After 3 days of cultivation, cells were inoculated with $200 \mu \mathrm{L}$ of a virus stock containing $10^{5} \mathrm{TCID}_{50} / \mathrm{mL}$ of four different PRRSV strains grown on PAMs: LV, Lena, MN-184 and VR2332. After 0, 12, 24, 48 and 72 hours post-inoculation (hpi), supernatant was collected, centrifuged (10 $\mathrm{min}, 300 \mathrm{~g}, 4{ }^{\circ} \mathrm{C}$ ) and stored at $-70{ }^{\circ} \mathrm{C}$ prior to virus titration on PAM [6]. Cells on inserts were fixed with methanol at the indicated time points and stained for immunofluorescence analysis. The PRRSV $\mathrm{N}$ protein was stained with primary mAb $13 \mathrm{E} 2$ directed against PRRSV nucleocapsid $\left(\operatorname{IgG}_{1}, 1: 50\right)$ and secondary FITC-conjugated polyclonal goat anti-mouse IgG antibodies (Invitrogen, Molecular Probes, Belgium). Virus positive cells were counted on images acquired with a TCS SPE confocal system (Leica Microsystems $\mathrm{GmbH}$, Germany). Twenty images were taken for each experimental condition, and the percentage of infected cells was assessed with Image J.

Furthermore, another ten genetically different viral strains were used for comparison of the replication in both PK15 $5^{\mathrm{S} 10-\mathrm{CD} 163}$, PK15 ${ }^{\mathrm{S} 1-\mathrm{CD} 163}$ cell line using the sample protocol as described above (Table 1). The ten different PRRSV strains grown on PAMs were: 94V360,
07V063, 08VA, 13V091, 13V117, 17V024, Korean17, Su1-Bel, NADC 30, SDSU73.

\section{Statistical analysis}

Infection experiments for the four prototype strains were performed with at least three replicates. Results were compared using a two-way ANOVA test (GraphPad Prism 5) followed by Šidak's multiple comparisons test. Differences were considered statistically significant at $p<0.05$. Variance between intracellular and extracellular titers for the two cell lines were analyzed in univariate main effect model with SPSS. Differences were considered statistically significant at $p<0.05$.

\section{Results}

Construction of PK15 1 S10-CD163 and detection of receptors in the PK15 $5^{\text {S1-CD163 and PK15 }}{ }^{\text {S10-CD163 }}$ cell lines

by immunofluorescence staining and flow cytometry

PK15 cells, stably expressing Siglec-10 (PK15 $\left.{ }^{\mathrm{S} 10}\right)$ were produced as previously described [18]. Then, PK $15^{\mathrm{S} 10}$ cells were transfected with CD163 and screened with zeocin and followed by Facs sorting for selection of double receptors positive cell clones as indicated in Figure 1. The presence of Siglec-10 and CD163 was confirmed by immunofluorescence staining (Figure 1). The cells maintained a stable expression of Siglec-10 and CD163 for at least 15 passages. PK15 $5^{\text {S1-CD163 }}$ cells were previously produced by Delrue et al. [10]. Expression of Siglec-1, Siglec-10 and CD163 was analyzed in PK15 $5^{\text {S1-CD163 }}$ and PK15 $5^{\text {S10-CD163 }}$ cells with immunofluorescence staining and flow cytometry. As shown in Figure 2, the PK15 ${ }^{\mathrm{S} 1-\mathrm{CD} 163}$ cells were positive for Siglec-1 and CD163, but negative for Siglec-10. PK15 ${ }^{\text {S10-CD163 }}$ cells on the other hand were positive for Siglec-10 and CD163, but negative for Siglec-1. PK15 cells were negative for all of the three receptors (Figure 2).

\section{Attachment, internalization, disassembly and infection of PK15 1 1-CD163 and PK15 ${ }^{\text {S10-CD163 }}$ cells with PRRSV}

Our aim was to compare the attachment, internalization, disassembly and infection of PRRSV in the PK15 ${ }^{\text {S10-CD163 }}$ and PK15 $5^{\text {S1-CD163 }}$ cell lines. As shown in Figure 3, virus particles clearly attached to cells of both cell lines and subsequently were internalized into the cells. After internalization, the virus particles were uncoated in order to release the viral genome. Finally, infection occurred (Figure 3). In general, in line with the binding and entry results, the LV strain infected PK15 ${ }^{\text {S1-CD163 }}$ cells better than PK15 ${ }^{\text {S10-CD163 }}$ cells. 

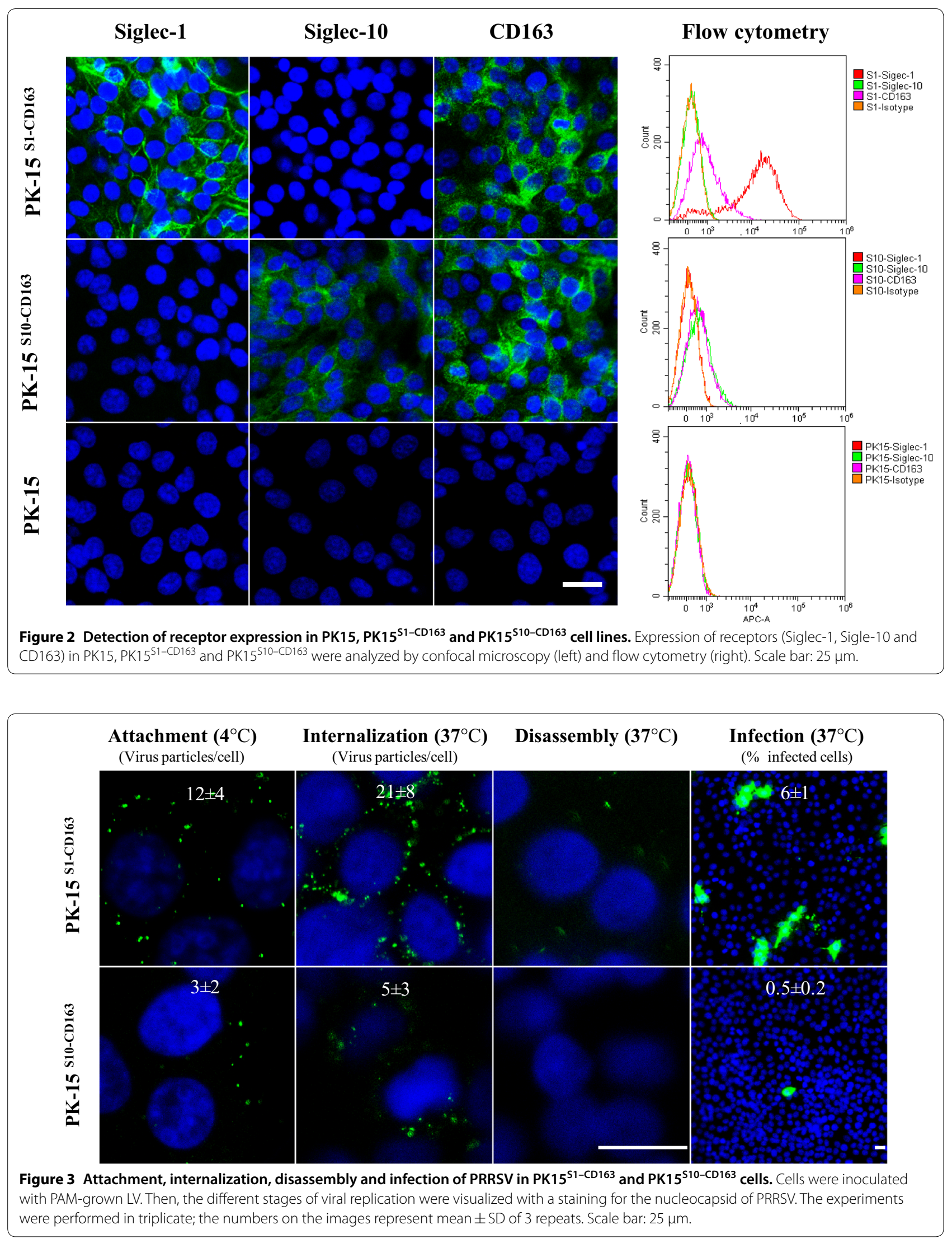
Infection kinetics in PK15 $5^{\mathrm{S1-CD} 163}$ and PK15 $5^{\mathrm{S10-CD163}}$ cells upon inoculation with genotype I (LV and Lena) and II (VR2332, MN184) PRRSV reference strains PK15 $5^{\mathrm{S} 1-\mathrm{CD} 163}$ and PK15 $5^{\mathrm{S} 10-\mathrm{CD} 163}$ cells were inoculated with PAM-grown LV, Lena, MN-184 and VR2332 and at $1,12,24,48$ and $72 \mathrm{hpi}$, cells were fixed and stained by immunofluorescence. Figure 4 shows that the two cell lines are susceptible to all used PRRSV strains and that the infection level increased with time. In general, PAMgrown Lena and MN-184 strains could infect PK15 1 S1CD163 and PK15 ${ }^{\mathrm{S} 10-\mathrm{CD} 163}$ cells more efficiently than the prototype LV and VR2332 strains $(p=0.0081)$. The percentage of cells infected with LV, Lena, and VR2332 strains was significantly higher in PK15 $15^{\text {S1-CD163 }}$ cells than in PK15 $5^{\mathrm{S} 10-\mathrm{CD} 163}$ cell line $(p<0.0001)$. The PAMgrown $\mathrm{MN}-184$ strain showed a significantly higher
A

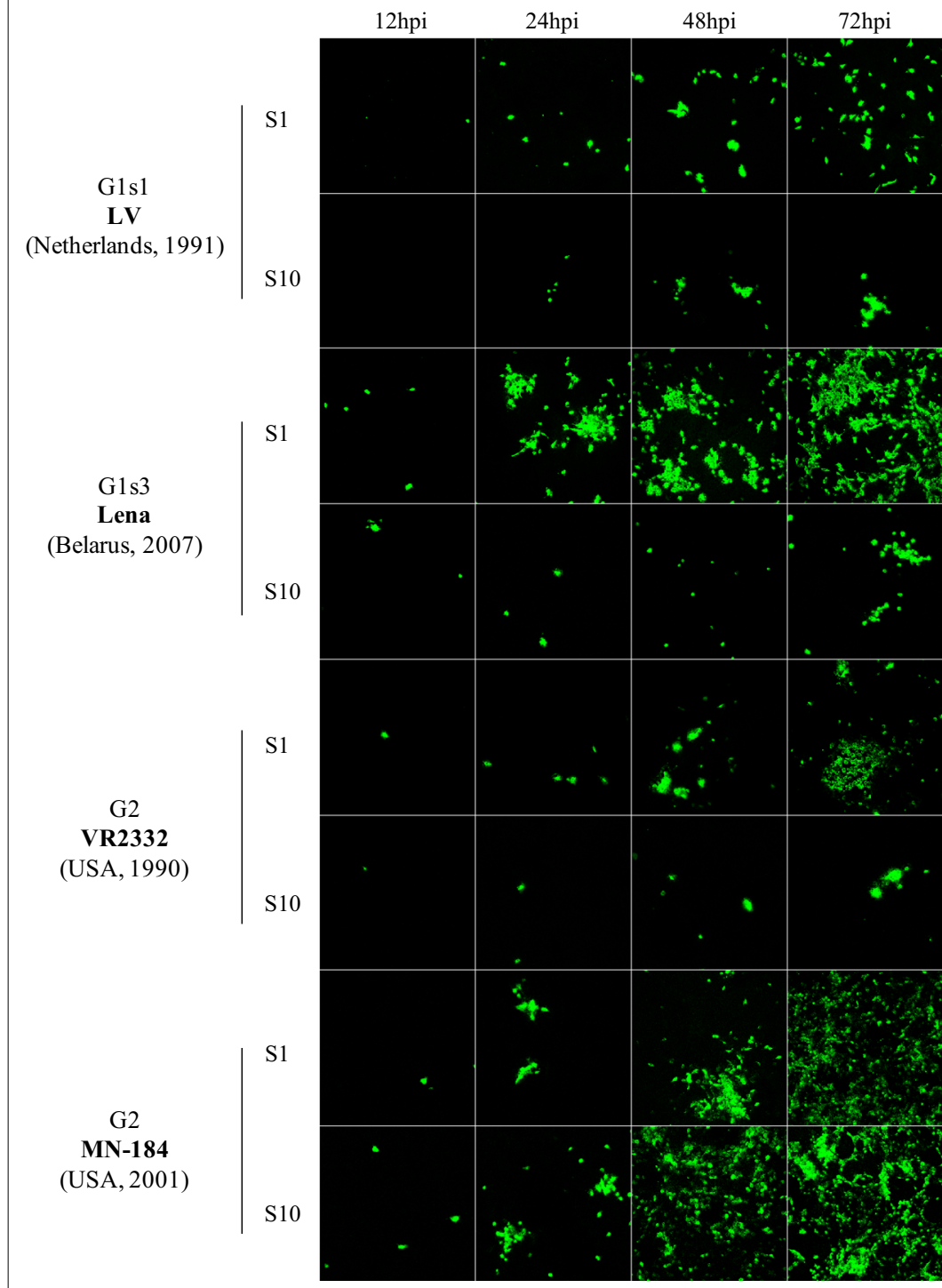

B
(\%) $\quad\left(\log _{10} \mathrm{TCID}_{50} / \mathrm{mL}\right)$

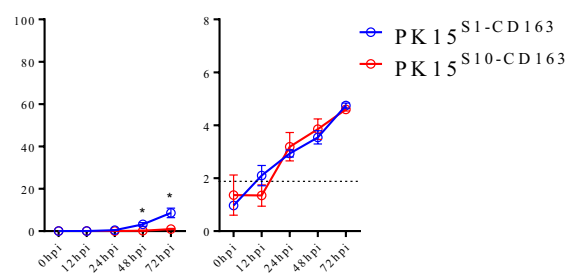

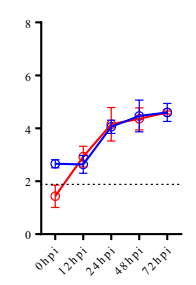
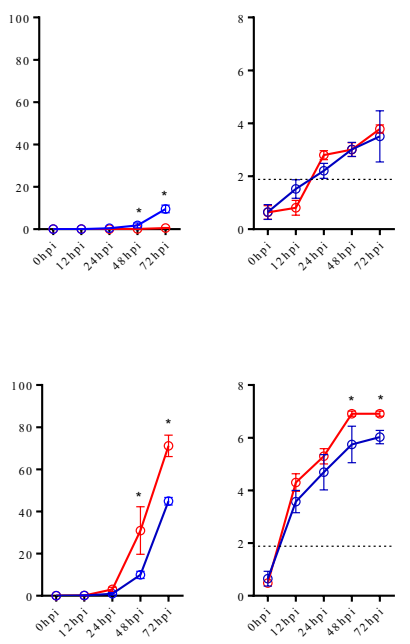

Figure 4 PRRSV infection kinetics in PK15 $5^{\text {S1-CD163 and PK15 }} 5^{\text {S10-CD163 }}$ cells. Cells were inoculated with PAM-grown PRRSV strains (LV, Lena, VR-2332 and MN-184). After 0, 12, 24, 48 and $72 \mathrm{~h}$ of infection, cells were fixed and an immunofluorescence staining was performed (A). The number of infected cells was counted and expressed as percentage of infected cells (B). In addition, the virus titers in supernatants were determined. The blue line represents the kinetics of the virus infection rate/titers in PK1 $5^{S 1-C D 163}$ cells, while the red line represents the kinetics of the virus infection rate/titer in PK15 $5^{\mathrm{S10}-\mathrm{CD} 163}$ cells. G1s1= genotype 1 subtype $1 ; \mathrm{G} 1 \mathrm{~s} 3=$ genotype 1 subtype $3 ; \mathrm{G} 2=$ genotype $2 ; \mathrm{S} 1=\mathrm{PK} 15^{\mathrm{S1}-\mathrm{CD} 163}, \mathrm{~S} 10=\mathrm{PK} 15^{\mathrm{S} 10-}$ ${ }_{C D} 163$. Value of titers and infection proportion presented on the curve graph represent mean \pm SD of three experiments. Scale bar: $200 \mu \mathrm{m}$. 
infection rate in $\mathrm{PK} 15^{\mathrm{S} 10-\mathrm{CD} 163}$ cells $(71.2 \pm 5.1 \%)$ than in PK15 ${ }^{\mathrm{S} 1-\mathrm{CD} 163}$ cells $(44.9 \pm 1.8 \%, p<0.0001)$. For the LV and VR2332 strains, the virus replication kinetics was 5-12 fold lower compared to the MN-184 and Lena strains; infection was observed only in some cells both for $\mathrm{PK} 15^{\mathrm{S} 1-\mathrm{CD} 163}$ and $\mathrm{PK} 15^{\mathrm{S} 10-\mathrm{CD} 163}$ cells. Interestingly, although there is a higher infection rate for LV, Lena and VR2332 strains in PK15 ${ }^{\text {S1-CD163 }}$ than PK15 ${ }^{\text {S10-CD163 }}$ cells, the virus production in both cell lines was similar. This points towards a higher virus yield per cell for the PK15 ${ }^{\text {S10-CD163 }}$ cells. For the MN-184 strain, a higher virus infection rate and also a higher virus production were found in PK15 ${ }^{\mathrm{S} 10-\mathrm{CD} 163}$ cells.

\section{Analysis of Siglec-1, Siglec-10 and CD163 surface and cytoplasm expression in PK15 1 S1-CD163 and PK15 ${ }^{\text {S10-CD163 }}$ cells}

Based on the results of the binding and internalization assays, we found that irrespective of the PRRSV strain more virus particles were attached and internalized in the PK15 ${ }^{\mathrm{S} 1-\mathrm{CD} 163}$ cells. This might explain the higher virus infection rates in PK15 ${ }^{\mathrm{S} 1-\mathrm{CD} 163}$ cells for the LV, Lena and VR2332 strains. Interestingly, a similar virus production was observed for both cell lines, which might indicate that the virus particles are more anchored to the surface of the PK15 ${ }^{\text {S1-CD163 }}$ cells rather than released in the extracellular environment. As shown Siglec- $1^{+}$cells showed more binding of virus particles than Siglec- $10^{+}$ cells. We hypothesize that produced virus is anchored at the cell surface, preventing the release of virus particles. To show differences in subcellular expression patterns of Siglec-1 and Siglec-10, we performed a surface and intracellular staining. As shown in Figure 5, Siglec-1 is expressed on the surface of PK $15^{\mathrm{S} 1-\mathrm{CD} 163}$ cells to a higher level than Siglec-10 on the surface of PK15 $5^{\mathrm{S} 10-\mathrm{CD} 163}$ cells. In both cell lines, CD163 is expressed on the surface and in the cytoplasma with little difference between the two cell lines.

\section{Replication kinetics of ten genetically distant PRRSV strains in PK15 $5^{\mathrm{S1-CD} 163}$ and PK15 $5^{\mathrm{S10}-\mathrm{CD} 163}$ cells}

To analyze the possible Siglec preference of different PRRSV strains, we assessed the virus infection/production of additionally 7 genotype 1 subtype 1 strains (G1s1) (94V360, 07V063, 08VA, 13V091, 13V117, 17V035); 1 genotype 1 subtype 3 (G1s3) strains (Su1-Bel) and 3 genotype 2 strains (SDSU-73, NADC30-like and Korea17). Replication kinetics (both virus infection and virus production) were compared in the two cell lines (Figure 6). In general, the PK15 ${ }^{\mathrm{S} 10-\mathrm{CD} 163}$ cell line exhibited a higher efficiency in virus production per infected cell as compared to PK15 ${ }^{\mathrm{S} 1-\mathrm{CD} 163}$ (Additional file 1). For G1s1 strains, 07V063 strain preferred PK15 ${ }^{\mathrm{S1-CD163}}$, whereas the
94V360 and 08VA strains preferred PK15 ${ }^{\mathrm{S} 10-\mathrm{CD} 163}$. The highly virulent G1s3 strains (Su1-Bel and Lena) showed a strong preference for PK15 $5^{\mathrm{S1}-\mathrm{CD} 163}$. Similarly, to the genotype 2 strain $\mathrm{MN}-184$ in the previous infection assay, the other two genotype 2 strains, SDSU-73 and Korea17, also showed a higher infection rate in $\mathrm{PK} 15^{\mathrm{S} 10-\mathrm{CD} 163}$ as compared to PK $15^{\mathrm{S} 1-\mathrm{CD} 163}$ (84.3\% vs $38.7 \%$ and $34.93 \%$ vs $18.7 \%$, respectively). However, there were no significant differences between PK $15^{\mathrm{S1}-\mathrm{CD} 163}$ and PK $15^{\mathrm{S} 10-\mathrm{CD} 163}$ upon infection with VR2332 and NADC30 strains. Some strains (08VA (G1s1), 13V117 (G1s1), VR2332 (G2)) were poor virus producers $\left(<10^{4} \mathrm{TCID}_{50} / \mathrm{mL}\right)$, while other strains (07V063 (G1s1), 13V091 (G1s1), Su1-Bel (G1s3), MN-184 (G2), Korean17 (G2) and SDSU-73 (G2)) easily grew up to $\geq 10^{6} \mathrm{TCID}_{50} / \mathrm{mL}$. To confirm that the virus particles are better attached to the PK15 $5^{\mathrm{S1-CD} 163}$ cells, leading to a lower efficiency in virus production, both intracellular and extracellular virus titrations were performed for the ten genetically distant virus strains. Interestingly, we found that PK15 ${ }^{\mathrm{S} 10-\mathrm{CD} 163}$ cells showed much higher extracellular than intracellular virus titers (average titer of $3.41 \log _{10} \mathrm{TCID}_{50} / \mathrm{mL}$ vs $2.46 \log _{10} \mathrm{TCID}_{50} / \mathrm{mL}$, $p=0.005)$. However, for PK $15^{\mathrm{S} 1-\mathrm{CD} 163}$ cells, the intracellular and extracellular virus titers were comparable (average titer of $2.31 \log _{10} \mathrm{TCID}_{50} / \mathrm{mL}$ vs $2.45 \log _{10} \mathrm{TCID}_{50} / \mathrm{mL}$, $p=0.564)$ (Additional file 2).

\section{Discussion}

In vivo, PRRSV shows a strict preference for certain macrophage subsets, such as porcine alveolar macrophages (PAM). These primary porcine cells can be used for virus isolation and virus propagation, because they closely mimic the in vivo situation. However, using primary cell lines is expensive and may be a risk for contamination. More importantly, primary cells have a short lifespan and display a batch to batch variation. Apart from PAM, the other cell type known to be permissive to PRRSV is the immortalized monkey kidney cell line MA-104 and its derivatives, such as MARC-145 [11, 22]. This cell line is able to overcome the aforementioned problems and is routinely used for large scale production of PRRSV. However, the use of MARC-145 cell line is limited for virus isolation as some strains (most genotype 1 strains and a certain percentage of genotype 2 strains such as the Korean 17) do not grow in this cell line [23, 24]. In addition, the propagation of PRRSV in MARC-145 cells may lead to genetic changes [25]. The latter feature is used for the development of attenuated vaccines.

Non-permissive cells transiently transfected with CD163 may allow a low level of infection depending on the cell type used for virus replication [26]. Co-expression of Siglec-1 and the scavenger receptor CD163 are needed for an efficient PRRSV infection [27]. In our 


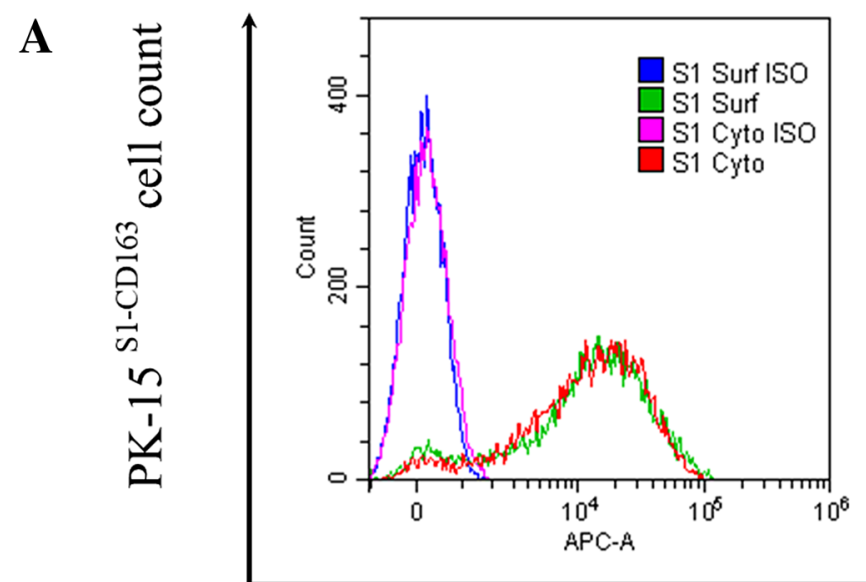

Siglec-1

B

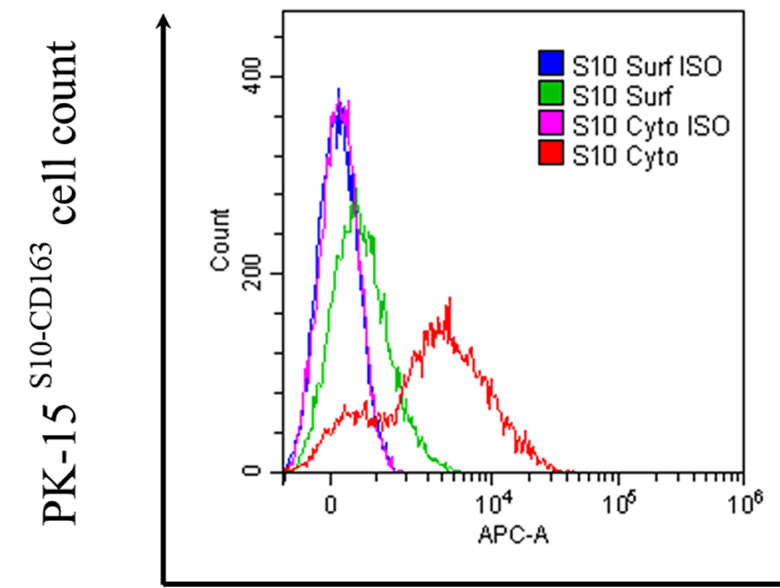

Siglec-10

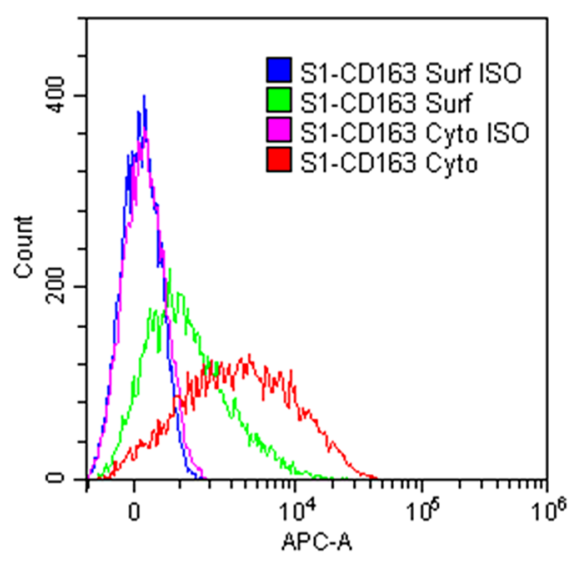

CD163

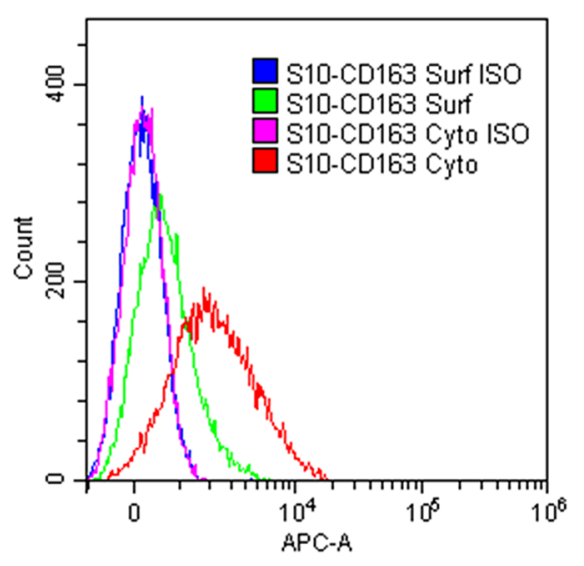

\section{CD163}

Figure 5 Flow cytometric analysis of receptor subcellular expression pattern for PK15 $5^{\mathrm{S1}-\mathrm{CD} 163}$ and PK15 $5^{\mathrm{S10}-\mathrm{CD} 163}$ cell lines. Siglec-1, Siglec-10 and CD163 expression in the cytoplasm and on the plasma membrane of PK15 ${ }^{\text {S1-CD163 }}$ (A) and PK15 ${ }^{\text {S10-CD163 }}$ (B) cells were analyzed with flow cytometry. Surf = surface expression; $c y t o=$ surface + cytoplasmic expression; ISO = isotype-matched control

search to find a cell line that combines the advantages of PAM and MARC-145, our laboratory has already successfully generated a PK15 cell line expressing both Siglec-1 and CD163 (PK15 ${ }^{\text {S1-CD163 }}$. However, we have recently shown that Siglec- 1 is not the only entry mediator for PRRSV [18]. As for Siglec-1, Siglec-10 in combination with CD163 is also able to improve PRRSV infection in non-permissive cells. Siglec-10 facilitates attachment and internalization of PRRSV. To assess if the receptor use differs between different PRRSV strains, we constructed a PK15 cell line recombinantly expressing Siglec-10 and CD163 (PK15 ${ }^{\text {S10-CD163 }}$. Expression of both receptors was confirmed with immunofluorescence and flow cytometry.
PRRSV entry in the target cells is initiated via virusreceptor interaction. First, the virus binds to heparin sulphate as well as sialoadhesin, and then, virus is internalized via sialoadhesin through its interaction with the PRRSV GP5-M structural protein complex. Following entry, CD163 coordinates disassembly and the following steps in the virus replication cycle. Previously, we have shown that $\mathrm{PK} 15^{\mathrm{S} 10}$ cells were able to bind and internalize PRRSV particles, however, no productive infection could be observed [18]. In this study, CD163 was successfully introduced in the PK15 ${ }^{\mathrm{S} 10}$ cells. The complete replication cycle was analyzed and compared with those in PK15 ${ }^{\mathrm{S} 1-\mathrm{CD} 163}$ cells. As expected, both cell lines were susceptible for PRRSV infection. Attachment, 


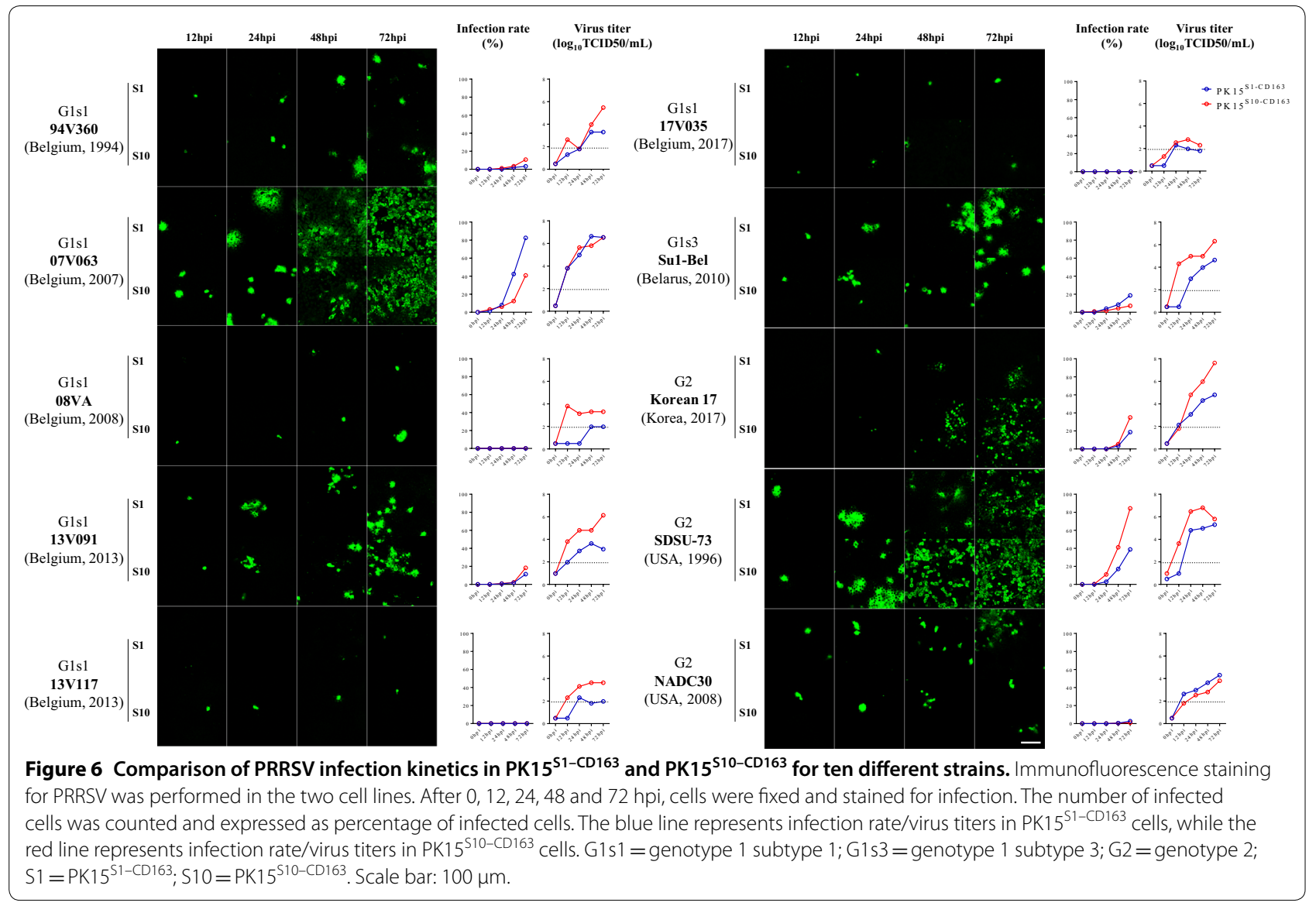

internalization, disassembly and infection of LV occurred in both cell lines.

The binding and internalization were at a lower level in the PK15 10 10-CD163 cells. We hypothesized that this was due to a different subcellular expression pattern of Siglec-1 and Siglec-10. Siglec-1 is expressed to higher levels on the surface of the cells than Siglec-10. This might partly explain the more efficient binding and internalization in PK15 ${ }^{\mathrm{S} 1-\mathrm{CD} 163}$ cells. As the CD163 expression is similar in both cell lines, the observed differences can only be attributed to the Siglec localization patterns.

In order to determine the efficiency of PRRSV infection and production in $\mathrm{PK} 15^{\mathrm{S} 10-\mathrm{CD} 163}$ compared to $\mathrm{PK} 15^{\mathrm{S} 1-}$ CD163 cells, a PRRSV replication kinetic experiment with 14 different virus strains was performed. Information on these strains is listed in Table 1. Based on the phylogenetic tree analysis (Additional file 3), the 14 strains used for this study are genetically distant. Significant variability in growth characteristics among genetically distant strains was observed. Some strains [08VA (G1s1), 13V117 (G1s1), VR2332 (G2)] were poor virus producers $\left(<10^{4} \mathrm{TCID}_{50} / \mathrm{mL}\right)$, while other strains [07V063 (G1s1), 13V091 (G1s1), Su1-Bel (G1s3), MN-184 (G2), Korean17 (G2) and SDSU-73 (G2)] easily grew up to $\geq 10^{6} \mathrm{TCID}_{50} /$ $\mathrm{mL}$. Interestingly, a previous study from Frydas et al. [16] has shown that the PRRSV strains LV, 08VA and 13V117 were also categorized as poor growers, Lena and VR2332 strains were moderate, while the 07V063, 13V091 and $\mathrm{MN}-184$ strains were strong producers based on virus shedding in respiratory explants $[15,16]$. The Korean 17 (G2) strain is a recent type 2 strain isolated from a farm with a severe outbreak of PRRS. Our results are consistent with the idea that the virulence is associated with a faster replication in both cell lines. To further analyze the replication of all of the strains, we found that strains LV, 07V063, Sul-Bel, Lena, VR2332 and NADC30 performed better in PK15 $5^{\mathrm{S1}-\mathrm{CD} 163}$ cells, whereas 94V360, 08VA, 13V091, 13V117, MN-184, SDSU-73 and Korean17 strains preferred PK15 ${ }^{\mathrm{S} 10-\mathrm{CD} 163}$. Interestingly, the genotype 1 subtype 3 strains (Lena and Su1-Bel) showed a stronger preference for $\mathrm{PK} 15^{\mathrm{S1-CD} 163}$ cells, while the highly pathogenic type 2 strains (MN-184, SDSU-73, 
Korean17) showed a higher affinity to PK $15^{\mathrm{S} 10-\mathrm{CD} 163}$ cells. The other two genotype 2 strains, VR2332 and NADC30, showed a slight preference to PK15 ${ }^{\mathrm{S} 1-\mathrm{CD} 163}$ cells. A previous study [15] revealed that VR2332 mainly infects $\mathrm{Sn}^{+}$cells in the lamina propria of the nasal mucosa, whereas the other genotype 2 strains (MN-184, VN) were also able to infect large number of $\mathrm{Sn}^{-}$cells. This might explain the preference for the cell line observed in this study. No data for the NADC30 strain is available in the ex vivo explant model. However, it was shown that NADC30 strain is relatively less pathogenic compared to MN-184 and SDSU-73 [28]. In return, we can assume that NADC30 might have a relatively more restricted cell tropism compared to the MN-184 and SDSU-73 strains. GP5 is the major glycoprotein of PRRSV. Sugar modification of this viral glycoprotein is important for host-pathogen interactions and signaling recognition. Previously, we have shown that Siglec-1 interacts with the GP5/M heterodimer complex [12]. Siglec-10 functions in a similar way as Siglec-1 in mediating the binding and internalizing of the virus in a sialic acid-dependent manner [18]. Here we further analyzed the amino acid sequence of GP5 for all of the virus strains used in our study with MEGA 6. The first two glycosylation sites ( $\mathrm{N}$ at position 10 and 17) are fully conserved and are present in all PRRSV strains, demonstrating its crucial role in the binding/internalization process. The third potential N-glycosylation further away from the membrane is more variable (Figure 7). It is highly possible that this variation influences the attachment and internalization due to a siglec preference. The majority of type 2 strains (MN-184, SDSU-73 and Korean 17) carry around 3-4 glycosylation sites $\left(\mathrm{N}^{10}, \mathrm{~N}^{17}, \mathrm{~N}^{27} / \mathrm{N}^{28} / \mathrm{N}^{29}, \mathrm{~N}^{31}\right)$ and show a preference for Siglec-10. LV, VR2332 and Lena show a highly preference for Siglec-1. LV has only two glycosylation sites $\left(\mathrm{N}^{10}, \mathrm{~N}^{17}\right)$. Although VR2332 has four potential N-glycosylation sites, only 2 or exceptionally $3 \mathrm{~N}$-glycosylation sites are used in nature $\left(\mathrm{N}^{10}, \mathrm{~N}^{17}, \pm \mathrm{N}^{28}\right)[29,30]$, with a poor glycosylation efficiency of the NDS sequon for $\mathrm{N}^{28}$. What Lena concerns, a non-conserved mutation $42 \mathrm{Q}$ (polar uncharged) to 42L (hydrophobic) between $\mathrm{N}^{17}$ and $\mathrm{N}^{26}$ glycosylation site was observed, which changes from an amino acid with an uncharged side chain into a hydrophobic side chain, which might have an impact on the glycosylation modification. However, whether the differences in $\mathrm{N}$-glycosylation sites in the ectodomain of GP5 result in different glycosylation patterns that are related to the preference in usage of Siglecs needs further investigations.

The production of virus by infected cells is an essential process for the spread of viral diseases. Enveloped viruses can spread via two distinct routes, either through the cell-free aqueous environment or by direct cell-cell contact. In the present study, we found that the PK $15^{\mathrm{S} 10-}$ ${ }^{C D 163}$ cell line exhibited a higher efficiency in virus release in the extracellular environment than the $\mathrm{PK} 15^{\mathrm{S1}-\mathrm{CD} 163}$ cell line (Additional file 1). The prototype strains (LV, Lena, VR2332) showed a much higher infection rate in the PK15 ${ }^{\mathrm{S} 1-\mathrm{CD} 163}$ cell line, but the virus titers in the supernatant were comparable in both cell lines. Two possible mechanisms may be forwarded for this phenomenon. First, virus might use more cell-to-cell transmission in PK15 $5^{\mathrm{S} 1-\mathrm{CD} 163}$ cells as compared to PK15 ${ }^{\mathrm{S} 10-\mathrm{CD} 163}$ cells giving rise to a higher infection rate but lower virus release. Second, based on the surface and cytoplasm staining, Siglec-1 is more abundantly expressed on the surface of the cells providing more efficient binding and internalization, while Siglec-10 is mostly expressed in the cytoplasm. This might increase the chance that upon release from the cells, the virus particles bind back to the surface of the PK15 ${ }^{\mathrm{S} 1-\mathrm{CD} 163}$ cells. This hypothesis is supported by the observation that the extracellular titers were higher for the PK15 ${ }^{\mathrm{S} 10-\mathrm{CD} 163}$ cell line, while the intra- and extracellular virus titers are more or less the same for the PK15 $5^{\mathrm{S} 1-\mathrm{CD} 163}$ cell line (Additional file 1).

In summary, the observation that all tested virus strains replicate well in both $\mathrm{PK} 15^{\mathrm{S} 1-\mathrm{CD} 163}$ and $\mathrm{PK} 15^{\mathrm{S} 10-\mathrm{CD} 163}$ cells suggesting that these cells might be useful for virus isolation. Today MARC-145 is the mostly used cell line for virus isolation, however, not all PRRSV strains grow on MARC-145 cells [11, 24]. PAM has a much higher efficiency in virus isolation, but it is more variable and more difficult for routine maintenance. The two cell lines that we constructed could be an optimal replacement for both MARC-145 and PAM. In addition, the PK15 $5^{\text {S10-CD163 cell }}$ line is more efficient in virus production, which is important for the production of inactivated vaccines. Finally, the observed variability in growth characteristics of all 


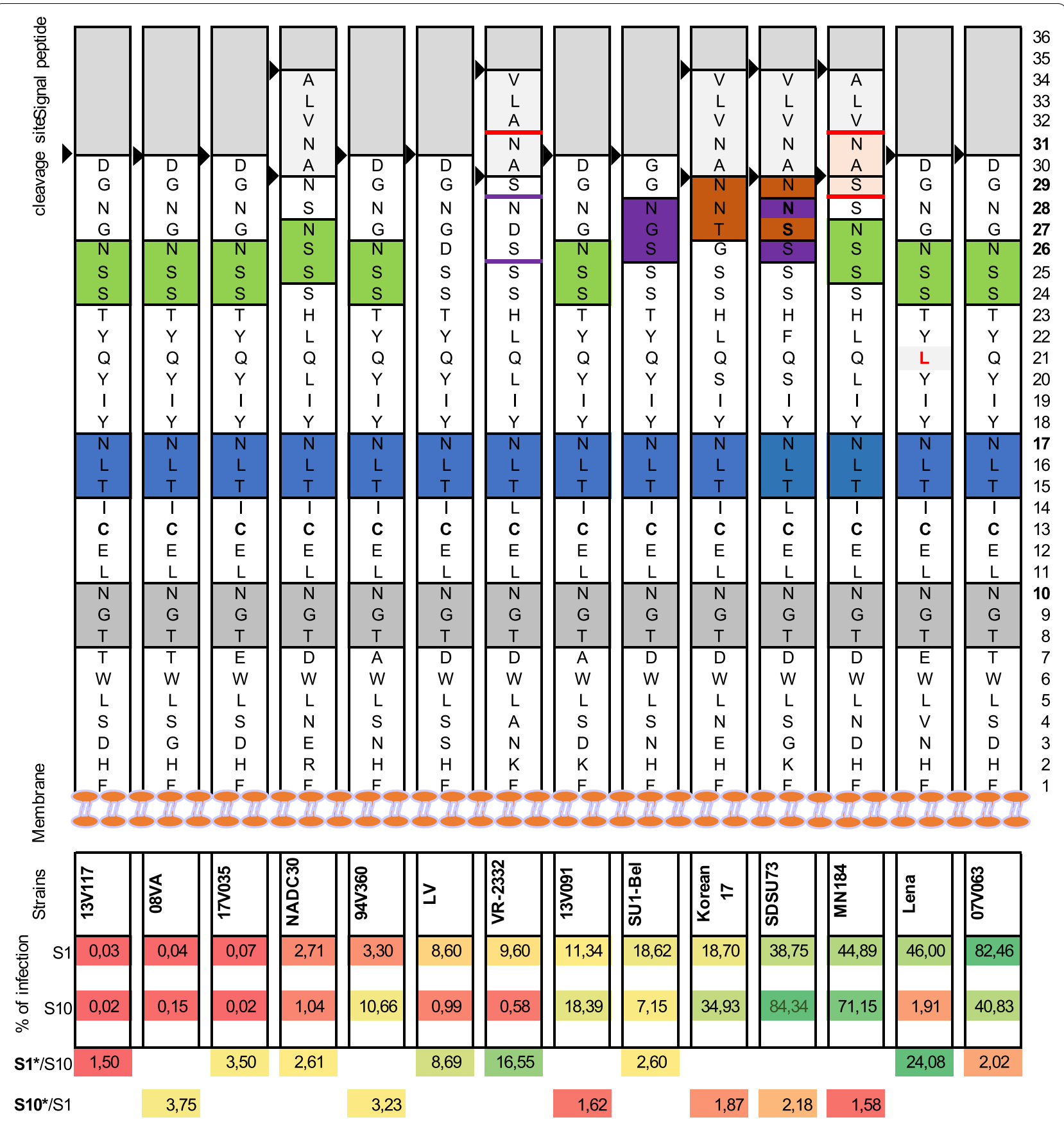

Figure 7 GP5 ectodomain amino acid and N-glycosylation site analysis for both type 1 and type 2 PRRSV strains. A graphic representation of an amino acid sequence alignment of the GP5 ectodomain, starting with the 1st amino acid (aa) at the plasma membrane. The potential glycosylation sites were indicated with colored boxes. The first $\mathrm{N}$ glycosylation site is $\mathrm{N}^{10}$ which is 10 aa away from the membrane (indicated with grey boxes). The second $\mathrm{N}$-glycosylation site $\mathrm{N}^{17}$ is colored blue. The third or fourth $\mathrm{N}$-glycosylation sites at $\mathrm{N}^{26} / \mathrm{N}^{27}$ is colored green, $\mathrm{N}^{28}$ is colored with purple and at $\mathrm{N}^{31}$ is colored with red. Black arrows represent the signal peptide cleavage site for GP5 protein. The virus strains were ranked on the infection rate in Siglec-1 expressing cells. The ranking is represented with a heat map (Red represent a low percentage, yellow represents a medium percentage and green represent high percentage). The preferences for Siglec-1 and Siglec-10 were indicated with an infection ratio of S1/ S10 or S10/S1. 
the virus strains tested in both cell lines might be connected with the outcome of a PRRSV infection and might be partially explained by the receptor usage.

\section{Additional files}

\section{Additional file 1. Comparison of virus production per infected cell} in PK-15 $5^{\mathrm{S1}-\mathrm{CD} 163}$ and PK15 $5^{\mathrm{S} 10-\mathrm{CD} 163}$ cells. Blue bars represent the virus production per infected cells of PK-1 $15^{51-C D 163}$. Red bars represent the virus production per infected cells of PK-15 $5^{\mathrm{S10}-\mathrm{CD} 163}$.

Additional file 2. Kinetics of intracellular and extracellular virus titers for 10 strains propagated in PK-15 ${ }^{\text {S1-CD163 }}$ and PK15 $15^{\text {S10-CD163 }}$ cells. Ten genetically distant PRRSV strains were inoculated in two cell lines. Cells and supernatants were collected separately for titration of extra- and intracellular virus. The blue solid (extracellular) and blue dashed lines (intracellular) represent the titration results for PK-15 $5^{\mathrm{S1-CD} 163}$. The red solid (extracellular) and red dashed lines (intracellular) represent the titration results for PK-15 $5^{\mathrm{S10-CD} 163}$ cells

Additional file 3. Phylogenetic tree of virus isolates used in the present study. A molecular phylogenetic analysis of the full genome nucleotide sequences was constructed using the Neighbor-Joining method. Phylogenetic relationships were estimated using the Clustal Omega method. The optimal tree is drawn to scale. Numbers indicate bootstrap values of 100 replicates. Strain nomenclature is as follows: GenBank accession number/Name of the isolate. Filled circles represent the strains used in the present study.

\section{Abbreviations}

D-MEM: Dulbecco's Modified Eagle Medium; FBS: fetal bovine serum; FITC: fluorescein isothiocyanate; G1s1: genotype 1 subtype 1; G1s2: genotype 1 subtype 3; G2: genotype 2; LV: Lelystad virus; MAG: myelin-associated glycoprotein; MEM: Modified Eagle Medium; MOI: multiplicity of infection; PAM: porcine alveolar macrophages; PBS: phosphate-buffered saline; PCD163: porcine cluster of differentiation 163; PF: paraformaldehyde; PK-15: porcine kidney cells; pSn: porcine sialoadhesin; PRRSV: porcine reproductive and respiratory syndrome virus; Siglec: sialic acid-binding immunoglobulin-type lectins.

\section{Competing interests}

The authors declare that they have no competing interests.

\section{Authors' contributions}

JX designed and performed the experiments, analyzed the data and helped to draft the manuscript. IT and BD assisted in sorting of cells. TC and BY participated in part of the experiment assays. IT, BD and RW helped in writing the paper. $\mathrm{HN}$ and IC conceived and designed the study and helped in writing the manuscript. All authors read and approved the final manuscript.

\section{Acknowledgements}

This research was supported by Research Foundation Flanders (FWO Vlaanderen—project G081214N), China Scholarship Council (201408440267) and Special Research Fund - Ghent University (cofunding CSC-grant). Bert Devriendt is supported by a postdoctoral research grant from FWO-Vlaanderen. We would like to acknowledge Carine Boone, Chantal Vanmaercke and Nele Dennequin for their excellent technical support.

\section{Publisher's Note}

Springer Nature remains neutral with regard to jurisdictional claims in published maps and institutional affiliations.

Received: 25 April 2018 Accepted: 6 July 2018

Published online: 18 July 2018

\section{References}

1. Snijder EJ, Meulenberg JJ (1998) The molecular biology of arteriviruses. J Gen Virol 79:961-979

2. Neumann EJ, Kliebenstein JB, Johnson CD, Mabry JW, Bush EJ, Seitzinger AH, Green AL, Zimmerman JJ (2005) Assessment of the economic impact of porcine reproductive and respiratory syndrome on swine production in the United States. J Am Vet Med Assoc 227:385-392

3. Pileri E, Mateu E (2016) Review on the transmission porcine reproductive and respiratory syndrome virus between pigs and farms and impact on vaccination. Vet Res 47:108

4. Duan X, Nauwynck HJ, Pensaert MB (1997) Virus quantification and identification of cellular targets in the lungs and lymphoid tissues of pigs at different time intervals after inoculation with porcine reproductive and respiratory syndrome virus (PRRSV). Vet Microbiol 56:9-19

5. Duan X, Nauwynck HJ, Pensaert MB (1997) Effects of origin and state of differentiation and activation of monocytes/macrophages on their susceptibility to porcine reproductive and respiratory syndrome virus (PRRSV). Arch Virol 142:2483-2497

6. Labarque GG, Nauwynck HJ, Van Reeth K, Pensaert MB (2000) Effect of cellular changes and onset of humoral immunity on the replication of porcine reproductive and respiratory syndrome virus in the lungs of pigs. J Gen Virol 81:1327-1334

7. Wang X, Eaton M, Mayer M, Li H, He D, Nelson E, Christopher-Hennings J (2007) Porcine reproductive and respiratory syndrome virus productively infects monocyte-derived dendritic cells and compromises their antigenpresenting ability. Arch Virol 152:289-303

8. Chang HC, Peng YT, Chang HL, Chaung HC, Chung WB (2008) Phenotypic and functional modulation of bone marrow-derived dendritic cells by porcine reproductive and respiratory syndrome virus. Vet Microbiol 129:281-293

9. Silva-Campa E, Cordoba L, Fraile L, Flores-Mendoza L, Montoya M, Hernandez J (2010) European genotype of porcine reproductive and respiratory syndrome (PRRSV) infects monocyte-derived dendritic cells but does not induce Treg cells. Virology 396:264-271

10. Delrue I, Van Gorp H, Van Doorsselaere J, Delputte PL, Nauwynck HJ (2010) Susceptible cell lines for the production of porcine reproductive and respiratory syndrome virus by stable transfection of sialoadhesin and CD163. BMC Biotechnol 10:48

11. Kim HS, Kwang J, Yoon IJ, Joo HS, Frey ML (1993) Enhanced replication of porcine reproductive and respiratory syndrome (PRRS) virus in a homogeneous subpopulation of MA-104 cell line. Arch Virol 133:477-483

12. Van Breedam W, Delputte PL, Van Gorp H, Misinzo G, Vanderheijden N, Duan X, Nauwynck HJ (2010) Porcine reproductive and respiratory syndrome virus entry into the porcine macrophage. J Gen Virol 91:1659-1667

13. Van Breedam W, Van Gorp H, Zhang JQ, Crocker PR, Delputte PL, Nauwynck HJ (2010) The M/GP(5) glycoprotein complex of porcine reproductive and respiratory syndrome virus binds the sialoadhesin receptor in a sialic acid-dependent manner. PLoS Pathog 6:e1000730

14. Van Gorp H, Van Breedam W, Van Doorsselaere J, Delputte PL, Nauwynck HJ (2010) Identification of the CD163 protein domains involved in infection of the porcine reproductive and respiratory syndrome virus. J Virol 84:3101-3105

15. Frydas IS, Nauwynck HJ (2016) Replication characteristics of eight virulent and two attenuated genotype 1 and 2 porcine reproductive and respiratory syndrome virus (PRRSV) strains in nasal mucosa explants. Vet Microbiol 182:156-162

16. Frydas IS, Trus I, Kvisgaard LK, Bonckaert C, Reddy VR, Li Y, Larsen LE, Nauwynck HJ (2015) Different clinical, virological, serological and tissue tropism outcomes of two new and one old Belgian type 1 subtype 1 porcine reproductive and respiratory virus (PRRSV) isolates. Vet Res 46:37

17. Prather RS, Rowland RR, Ewen C, Trible B, Kerrigan M, Bawa B, Teson JM, Mao J, Lee K, Samuel MS, Whitworth KM, Murphy CN, Egen T, Green JA (2013) An intact sialoadhesin (Sn/SIGLEC1/CD169) is not required for attachment/internalization of the porcine reproductive and respiratory syndrome virus. J Virol 87:9538-9546

18. Xie J, Christiaens I, Yang B, Breedam WV, Cui T, Nauwynck HJ (2017) Molecular cloning of porcine Siglec-3, Siglec-5 and Siglec-10, and identification of Siglec-10 as an alternative receptor for porcine reproductive and respiratory syndrome virus (PRRSV). J Gen Virol 98:2030-2042 
19. Nauwynck HJ, Pensaert MB (1995) Effect of specific antibodies on the cell-associated spread of pseudorabies virus in monolayers of different cell types. Arch Virol 140:1137-1146

20. Fuller SA, Takahashi M, Hurrell JG (2001) Cloning of hybridoma cell lines by limiting dilution. Curr Protoc Mol Biol 11(Unit11):8

21. Duan X, Nauwynck HJ, Favoreel H, Pensaert MB (1998) Porcine reproduc tive and respiratory syndrome virus infection of alveolar macrophages can be blocked by monoclonal antibodies against cell surface antigens. Adv Exp Med Biol 440:81-88

22. Bautista EM, Goyal SM, Yoon IJ, Joo HS, Collins JE (1993) Comparison of porcine alveolar macrophages and CL 2621 for the detection of porcine reproductive and respiratory syndrome (PRRS) virus and anti-PRRS antibody. J Vet Diagn Invest 5:163-165

23. de Abin MF, Spronk G, Wagner M, Fitzsimmons M, Abrahante JE, Murtaugh MP (2009) Comparative infection efficiency of Porcine reproductive and respiratory syndrome virus field isolates on MA104 cells and porcine alveolar macrophages. Can J Vet Res 73:200-204

24. Provost C, Jia JJ, Music N, Levesque C, Lebel ME, del Castillo JR, Jacques M, Gagnon CA (2012) Identification of a new cell line permissive to porcine reproductive and respiratory syndrome virus infection and replication which is phenotypically distinct from MARC-145 cell line. Virol J 9:267

25. Chen Y, He S, Sun L, Luo Y, Sun Y, Xie J, Zhou P, Su S, Zhang G (2016) Genetic variation, pathogenicity, and immunogenicity of highly pathogenic porcine reproductive and respiratory syndrome virus strain XH-GD at different passage levels. Arch Virol 161:77-86

26. Calvert JG, Slade DE, Shields SL, Jolie R, Mannan RM, Ankenbauer RG, Welch SK (2007) CD163 expression confers susceptibility to porcine reproductive and respiratory syndrome viruses. JVirol 81:7371-7379

27. Van Gorp H, Van Breedam W, Delputte PL, Nauwynck HJ (2008) Sialoadhesin and CD163 join forces during entry of the porcine reproductive and respiratory syndrome virus. J Gen Virol 89:2943-2953
28. Brockmeier SL, Loving CL Vorwald AC, Kehrli ME Jr, Baker RB, Nicholson TL, Lager KM, Miller LC, Faaberg KS (2012) Genomic sequence and virulence comparison of four Type 2 porcine reproductive and respiratory syndrome virus strains. Virus Res 169:212-221

29. Thaa B, Sinhadri BC, Tielesch C, Krause E, Veit M (2013) Signal peptide cleavage from GP5 of PRRSV: a minor fraction of molecules retains the decoy epitope, a presumed molecular cause for viral persistence. PLoS One 8:e65548

30. Li J, Tao S, Orlando R, Murtaugh MP (2015) N-glycosylation profiling of porcine reproductive and respiratory syndrome virus envelope glycoprotein 5. Virology 478:86-98

31. Van Breedam W, Costers S, Vanhee M, Gagnon CA, Rodriguez-Gomez IM, Geldhof M, Verbeeck M, Van Doorsselaere J, Karniychuk U, Nauwynck HJ (2011) Porcine reproductive and respiratory syndrome virus (PRRSV)specific mAbs: supporting diagnostics and providing new insights into the antigenic properties of the virus. Vet Immunol Immunopathol 141:246-257

32. Van Doorsselaere J, Brar MS, Shi M, Karniychuk U, Leung FC, Nauwynck HJ (2012) Complete genome characterization of a East European Type 1 subtype 3 porcine reproductive and respiratory syndrome virus. Virus Genes 44:51-54

33. Lu ZH, Wilson AD, Wang X, Frossard JP, StadejekT, Archibald AL, Ait-Ali T (2015) Complete genome sequence of a pathogenic genotype 1 subtype 3 porcine reproductive and respiratory syndrome virus (strain SU1-Bel) from pig primary tissue. Genome Announc 3:e00340-e00415

34. Benfield DA, Nelson E, Collins JE, Harris L, Goyal SM, Robison D, Christianson WT, Morrison RB, Gorcyca D, Chladek D (1992) Characterization of swine infertility and respiratory syndrome (SIRS) virus (isolate ATCC VR-2332). J Vet Diagn Invest 4:127-133
Ready to submit your research? Choose BMC and benefit from:

- fast, convenient online submission

- thorough peer review by experienced researchers in your field

- rapid publication on acceptance

- support for research data, including large and complex data types

- gold Open Access which fosters wider collaboration and increased citations

- maximum visibility for your research: over $100 \mathrm{M}$ website views per year

At $\mathrm{BMC}$, research is always in progress.

Learn more biomedcentral.com/submissions 